\title{
GRHL2 Gene
}

National Cancer Institute

\section{Source}

National Cancer Institute. GRHL2 Gene. NCI Thesaurus. Code C162372.

This gene plays a role in embyronic brain development and in epithelial development and maintenance. 